\title{
ステレオ視によるマニピュレータのビジュアルサーボ
}

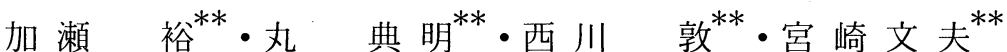

\section{Manipulator Control by Visual Servoing with Stereo Vision*}

\author{
Hiroshi $\mathrm{KASE}^{* *}$, Noriaki MARU ${ }^{* *}$, Atsushi Nishikawa ${ }^{* *}$ \\ and Fumio MiYAZAKI ${ }^{* *}$
}

\begin{abstract}
This paper presents a new method of visual servoing with stereo vision to control the position of a manipulator with respect to an object. Conventional control methods by visual servoing use a monocular camera and have several problems. For example, either shape information or desired distance of the target object from the camera must be given. Furthermore, it is not stable if the initial positional error of features in the image is very large. These problems are caused by image the Jacobian matrix, that is, the approximate value at desired position is used instead of correct one. By using stereo vision, the image Jacobian matrix can be calculated correctly at any position. So neither shape information nor desired distance of the target object is required. It is also stable even if the initial error is very large. Both simulation and experimental results are presented to demonstrate the effectiveness of this method.
\end{abstract}

\section{1.はじめに}

マニピュレータで, 物体を把握したり適当な場所に置 いたりするためには，手先を目標位置まで移動させなけ ればならない。乙のとき，内界センサだけでは外部環境 の変化に対応するてとは困難であり，外界センサにより 誤差を検出することが必要である，人間の場合は，主に 視覚を用いて誤差を検出するとにより，手先の位置を制 御していると考えられる. てのような視覚を用いたマニ ピュレータの制御方法は, ビジュアル・フィードバック と呼ばれている.

ビジュアル・フィードバックを実現する制御法には， 大きく分けて“ルック・アンド・ムーブ”と呼ばれる方 法と “ビジュアル・サーボ”之呼ばれる方法の二つが ある.ルック・アンド・ムーブは, カメラにより得られ る対象物体の位置・姿勢を, 環境に固定されたワールド 座標系に打ける 3 次元表現に变換し，ワールド座標系に おける目標位置へマニピュレータの手先を制御する手法

* 原稿受付 1992. 11. 26.

** 大阪大学 基礎工学部 Faculty of Engineering Science, Osaka University ; 1-1, Machikaneyama-cho, Toyonakacity, Osaka 560, JAPAN

Key Words : visual servoing, stereo vision, manipulator control, hand-eye system, image jacobian.
である．乙の方法では，ワールド座標系で手先の運動を 計画し, 逆運動学を介して各アクチュエータへの運動指 令を与えることになるため, マニピュレータやカメラ系 など，システムのキャリブレーションを正確に行う必要 がある。

てれに対して, ビジュアル・サーボは，画像中の特徴 量の変化とカメラの運動の変化を関係づけるヤコビ行列 (イメージャコビアンと呼ばれる) を用いることにより， 画像特徴を直接用いて状態量とするクローズな制御を行 う手法である，すなわち，ワールド座標系での位置計算 を行う必要が無いために，画像のみに基づくサーボ系を 構成でき, ルック・アンド・ムーブに比べ，キャリブレー ションエラーや環境の変化に対してロバストな制御が可 能となる.

ビジュアル・フィードバックでは，ハンドアイシステ ムと呼ばれるシステムがよく用いられるが, ハンドアイ システムは，カメラとマニピュレータを別々に配置した 方法とマニピュレータの手先にカメラを取り付けた方法 の二つに分けられる. 前者は, カメラ位置とマニピュレー タの手先位置がどちらあ移動するので, 手先がカメラの 死角に入らないようにするなどのマニピュレータの移動 戦略が複雑になるが, 後者は, カメラがマニピュレータ の手先に固定されているので，死角などを考慮する必要 
が無く, 画像により得られた情報から直接マニピュレー 夕を制御できる. 本論文では, 後者 (Fig.1参照) を 対象とする.

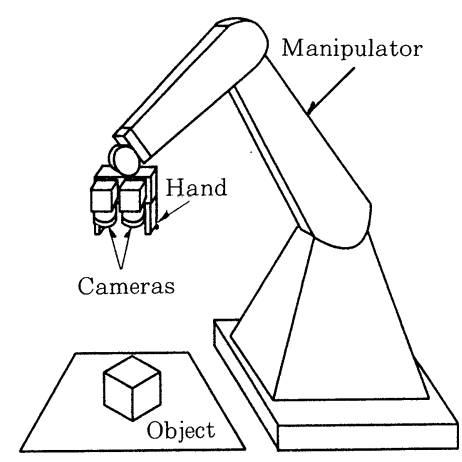

Fig. 1 Hand-eye system

従来の研究には, ビジュアル・サーボの応用として, ハンドアイシステムを用いた位置決めや特徵追跡などを 行った報告がいくつかある ${ }^{2) ~ 5)}$. 乙れらは，対象物体に 付けられた特徴点をカメラでとらえることにより, カメ ラと対象物体との目標とする相対関係を維持または達成 しようとするものである.

しかしながら，てれらの研究は，いずれ屯単眼力メラ によるハンドアイシステムであり，3 次元情報が 2 次元 情報へと落とされるため，必然的に人間の手により情報 を付け足す必要がある. たとえば，特徴点とカメラとの 3 次元的な距離情報（目標相対距離）をあらかじめ与え ておかなければならなかったり3，対象物体の形をモデ ルとしてあらかじめ記憶しておかなければならない22. ま た，初期誤差が大きい場合や特徵点の取り方によっては, 目標位置へ収束しないという問題点もある，乙れは，単 眼視におけるイメージャコビアンには，その要素中に画 像情報だけでは記述できない項があり，その值として近 似值を代入しているため, 目標位置でのみ正しい值をと り，それ以外の位置では近似值に過ぎないことに起因す るあのである.

本論文では，両眼カメラを用いたステレオ視により， これらの問題を解决する方法を提案する. ステレオ視に

Table 1 Definition of suffixes

\begin{tabular}{|ll|l|}
\hline \multicolumn{2}{|c|}{ Frame } & \multicolumn{1}{c|}{ Suffix } \\
\hline World Frame & $: \sum_{w}$ & $w$ (World) \\
Camera Frame & $: \sum_{c}$ & $c$ (Camera) \\
Left Image Frame & $: \sum_{l}$ & $l$ (Left) \\
Right Image Frame & $: \sum_{r}$ & $r$ (Right) \\
Virtual Image Frame & $: \sum_{I}$ & $I$ (Image) \\
Monocular Image Frame $: \sum_{m}$ & $m$ (Monocular) \\
\hline
\end{tabular}

より, 目標点近傍以外でも正しいイメージャコビアンを 計算することが可能となり, 目標相対距離や対象物体の モデルをあらかじめ与えなくてあ, また, 初期誤差が大 きい場合にも目標位置へ制御するととが可能となる.

以下では，ステレオ視のモデルとフィードバック入力 の生成方法について説明し，シミュレーションと実験に よりその有効性を示す.

\section{2. ステレオ視によるビジュアルサーボ}

\section{1 ステレオ視のモデル}

まず，ステレオ視における各座標系を定義し，ステレ オ視のモデルについて説明する. また, 各座標系におけ る值は, Table 1 の添字により表現することにする.

ここで用いたステレオ視のモデルは，一般に標準配置 のステレオ視モデルと呼ばれるもので，以下のような座 標系を定義する.

Fig. 2 に示すように, 2 台のカメラ中心を基線長 $b$ だ け離し，それらの光軸の方向が基線に対して直角になる ように配置し，2台のカメラ間の中心にカメラ座標系 $\Sigma_{c}$ の原点をとる. このとき, カメラ中心から光軸方向 に焦点距離 $f$ だけ離れた位置で光軸と直角に交わる平 面が画像平面であり, 光軸と画像平面の交点を左右それ ぞれ左画像座標系 $\sum_{l}$, 右画像座標系 $\sum_{r}$ の原点とする. また，ワールド座標系 $\sum_{w}$ は, 適当な位置に原点がとら れているものとする. 各座標系の $x, y, z$ 軸のとり方は, Fig. 2 に示すとおりとする.

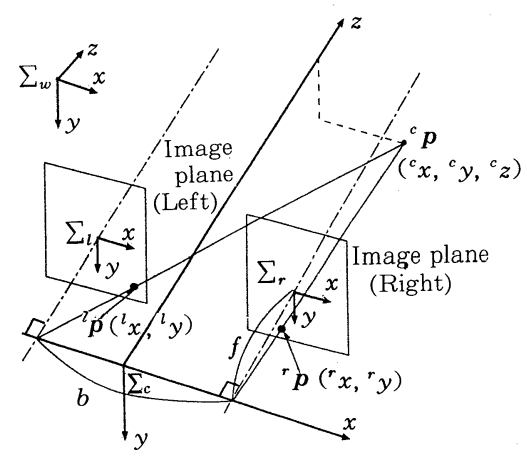

Fig. 2 Model of the stereo vision

このとき, カメラ座標系で ${ }^{c} \boldsymbol{p}=\left({ }^{c} x^{c} y^{c} z\right)^{\mathrm{T}}$ ( $\mathrm{T}$ は転 置を示す）と表わされる環境中の点 $p$ の左右の画像中 に写る像を，それぞれ ${ }^{l} \boldsymbol{p}=\left({ }^{l} x,{ }^{l} y\right),{ }^{r} \boldsymbol{p}=\left({ }^{r} x,{ }^{r} y\right)$ とす ると, 次式が成立する.

$$
{ }^{l} x=f \frac{{ }^{c} x+\frac{b}{2}}{{ }^{c} z}
$$




$$
\begin{aligned}
& { }^{r} x=f \frac{{ }^{c} x-\frac{b}{2}}{{ }^{c} z} \\
& { }^{l} y=f \frac{{ }^{c} y}{{ }^{c} z} \\
& { }^{r} y=f \frac{{ }^{c} y}{{ }^{c} z}
\end{aligned}
$$

以下では, 画像中の左右の特徵点のステレオ対応はとれ ているすのとする.

\section{2 イメージャコビアン}

ビジュアル・サーボでは, 画像中の特徽点の変化を利 用して手先の速度入力を生成するので, 画像中の特徽点 速度とカメラの移動速度の関係を詳しく知る必要がある. てれらを関係づける行列はイメージャコビアンと呼ばれ, 以下のようにして求めることができる.

いま, 対象物体上の $n$ 個の特徵点 $\boldsymbol{p}_{k}(k=1, \cdots, n)$ を考え, その画像中の座標を ${ }^{l} \boldsymbol{p}_{k}\left({ }^{l} x_{k},{ }^{l} y_{k}\right),{ }^{r} \boldsymbol{p}_{k}\left({ }^{r} x_{k}\right.$, $\left.{ }^{r} y_{k}\right)$ とする. 乙れら左右の画像座標をまとめて仮想的 な画像座標系 $I$ を定義し, 画像中の特徴点の現在位置 を次式のように記述する.

$$
{ }^{I} \boldsymbol{p}=\left({ }^{l} x_{1}{ }^{r} x_{1}{ }^{l} y_{1}{ }^{r} y_{1} \cdots{ }^{l} x_{n}{ }^{r} x_{n}{ }^{l} y_{n}{ }^{r} y_{n}\right)^{\mathrm{T}}
$$

ます, 簡単のために特徴点が 1 点の場合を考えると, 画像中の特徵点速度 ${ }^{I} \dot{\boldsymbol{p}}$ 亡カメラ座標系から見た特徵点 速度 ${ }^{c} \dot{\boldsymbol{p}}$ の間には，その相互関係を表わすヤコビ行列 ${ }^{I} J_{c}$ を用いて，次式の関係が成立する.

$$
{ }^{I} \dot{\boldsymbol{p}}={ }^{I} \boldsymbol{J}_{c}{ }^{c} \dot{\boldsymbol{p}}
$$

ただし，

$$
{ }^{I} J_{c}=\left(\begin{array}{lll}
\frac{\partial^{l} x}{\partial^{c} x} & \frac{\partial^{l} x}{\partial^{c} y} & \frac{\partial^{l} x}{\partial^{c} z} \\
\frac{\partial^{r} x}{\partial^{c} x} & \frac{\partial^{r} x}{\partial^{c} y} & \frac{\partial^{r} x}{\partial^{c} z} \\
\frac{\partial^{l} y}{\partial^{c} x} & \frac{\partial^{l} y}{\partial^{c} y} & \frac{\partial^{l} y}{\partial^{c} z} \\
\frac{\partial^{r} y}{\partial^{c} x} & \frac{\partial^{r} y}{\partial^{c} y} & \frac{\partial^{r} y}{\partial^{c} z}
\end{array}\right)
$$

である.乙れにステレオ視のモデル (1)〜 (4) 式を代入 すると以下のようになる。

$$
{ }^{I} J_{c}=f\left(\begin{array}{ccc}
\frac{1}{{ }^{c} z} & 0 & -\frac{{ }^{c} x+\frac{b}{2}}{{ }^{c} z^{2}} \\
\frac{1}{{ }^{c} z} & 0 & -\frac{{ }^{c} x-\frac{b}{2}}{{ }^{c} z^{2}} \\
0 & \frac{1}{{ }^{c} z} & -\frac{{ }^{c} y}{{ }^{c} z^{2}} \\
0 & \frac{1}{{ }^{c} z} & -\frac{{ }^{c} y}{{ }^{c} z^{2}}
\end{array}\right)
$$

また， カメラの各軸でとの並進移動速度を $\nu_{x}, \nu_{y}, \nu_{z}$, 回転角速度を $\omega_{x}, \omega_{y}, \omega_{z}$ とし, カメラの移動速度 $\boldsymbol{u}$ を

$$
\boldsymbol{u}=\left(\begin{array}{c}
\nu_{x} \\
\nu_{y} \\
\nu_{z} \\
\omega_{x} \\
\omega_{y} \\
\omega_{z}
\end{array}\right)=\left(\begin{array}{c}
{ }^{c} \nu_{c} \\
{ }^{c} \omega_{c}
\end{array}\right)
$$

と表わせば，カメラ座標系から見た特徴点速度 ${ }^{c} \dot{\boldsymbol{p}}$ は，

$$
\begin{aligned}
{ }^{c} \dot{\boldsymbol{p}} & =\frac{d^{c} \boldsymbol{p}}{d t} \\
& =\frac{d}{d t}{ }^{c} \boldsymbol{R}_{w}\left({ }^{w} \boldsymbol{p}^{-{ }^{w}} \boldsymbol{p}_{c}\right) \\
& ={ }^{c} \boldsymbol{R}_{w}\left\{{ }^{w} \boldsymbol{\omega}_{c} \times\left({ }^{w} \boldsymbol{p}^{-w} \boldsymbol{p}_{c}\right)\right\}+{ }^{c} \boldsymbol{R}_{w}\left({ }^{w} \dot{\boldsymbol{p}}-{ }^{w} \dot{\boldsymbol{p}}_{c}\right)
\end{aligned}
$$

と表わされる2). ただし, ${ }^{c} \boldsymbol{R}_{w}$ はカメラ座標系からワー ルド座標系への回転行列であり, ${ }^{w} \boldsymbol{p}_{c}$ などは, 左肩添字 の座標系から見た右下座標系の位置を表わしている. 対象物体は, ワールド座標系に固定されているので, ${ }^{w} \dot{\boldsymbol{p}}=0$ とすれば， ${ }^{\boldsymbol{c}} \dot{\boldsymbol{p}}$ と $\boldsymbol{u}$ は以下のような関係式で表わ すことができる.

$$
\begin{aligned}
{ }^{c} \dot{\boldsymbol{p}} & ={ }^{c} \boldsymbol{R}_{w}\left\{-{ }^{w} \boldsymbol{\omega}_{c} \times\left({ }^{w} \boldsymbol{p}^{-{ }^{w}} \boldsymbol{p}_{c}\right)\right\}-{ }^{c} \boldsymbol{R}_{w}{ }^{w} \dot{\boldsymbol{p}}_{c} \\
& =-{ }^{c} \boldsymbol{\omega}_{c} \times{ }^{c} \boldsymbol{p}-{ }^{c} \dot{\boldsymbol{p}}_{c}
\end{aligned}
$$

${ }^{c} \dot{\boldsymbol{p}}_{c}$ はカメラの移動速度を表わすので ${ }^{c} \boldsymbol{\nu}_{c}$ と等価である. よって以下を得る。

$$
\begin{aligned}
{ }^{c} \dot{\boldsymbol{p}} & =-\left(\begin{array}{c}
\omega_{x} \\
\omega_{y} \\
\omega_{z}
\end{array}\right) \times\left(\begin{array}{c}
{ }^{c} x \\
{ }^{c} y \\
{ }^{c} z
\end{array}\right)-\left(\begin{array}{c}
\nu_{x} \\
\nu_{y} \\
\nu_{z}
\end{array}\right) \\
& =\left(\begin{array}{c}
-\omega_{y}{ }^{c} z+\omega_{z}{ }^{c} y-\nu_{x} \\
-\omega_{z}{ }^{c} x+\omega_{x}{ }^{c} z-\nu_{y} \\
-\omega_{x}{ }^{c} y+\omega_{y}{ }^{c} x-\nu_{z}
\end{array}\right) \\
& =\left(\begin{array}{cccccc}
-1 & 0 & 0 & 0 & -{ }^{c} z & { }^{c} y \\
0 & -1 & 0 & { }^{c} z & 0 & -{ }^{c} x \\
0 & 0 & -1-{ }^{c} y & { }^{c} x & 0
\end{array}\right) \boldsymbol{u}
\end{aligned}
$$

したがって，(6)，(11）式より次式が得られる.

$$
\begin{aligned}
{ }^{I} \dot{\boldsymbol{p}} & ={ }^{I} \boldsymbol{J}_{c}{ }^{c} \dot{\boldsymbol{p}} \\
& ={ }^{I} \boldsymbol{J}_{c}\left(\begin{array}{cccccc}
-1 & 0 & 0 & 0 & -{ }^{c} z & { }^{c} y \\
0 & -1 & 0 & { }^{c} z & 0 & -{ }^{c} \boldsymbol{x} \\
0 & 0 & -1-{ }^{c} y & { }^{c} x & 0
\end{array}\right) \boldsymbol{u} \\
& =\boldsymbol{J} \boldsymbol{u}
\end{aligned}
$$




$$
J=f\left(\begin{array}{cccc}
-\frac{1}{{ }^{c} z} & 0 & \frac{{ }^{c} x+\frac{b}{2}}{{ }^{c} z^{2}} & { }^{c} y \frac{{ }^{c} x+\frac{b}{2}}{{ }^{c} z^{2}} \\
-\frac{1}{{ }^{c} z} & 0 & \frac{{ }^{c} x-\frac{b}{2}}{{ }^{c} z^{2}} & { }^{c} y \frac{{ }^{c} x-\frac{b}{2}}{{ }^{c} z^{2}} \\
0 & -\frac{1}{{ }^{c} z} & \frac{{ }^{c} y}{{ }^{c} z^{2}} & 1+\frac{{ }^{c} y^{2}}{{ }^{c} z^{2}} \\
0 & -\frac{1}{{ }^{c} z} & \frac{{ }^{c} y}{{ }^{c} z^{2}} & 1+\frac{{ }^{c} y^{2}}{{ }^{c} z^{2}} \\
-\left(1+{ }^{c} x\right. & \left.\frac{{ }^{c} x+\frac{b}{2}}{{ }^{c} z^{2}}\right) & \frac{{ }^{c} y}{{ }^{c} z} \\
- & \left(1+{ }^{c} x \frac{{ }^{c} x-\frac{b}{2}}{{ }^{c} z^{2}}\right) & \frac{{ }^{c} y}{{ }^{c} z} \\
-\frac{{ }^{c} x^{c} y}{{ }^{c} z^{2}} & -\frac{{ }^{c} x}{{ }^{c} z} \\
-\frac{{ }^{c} x^{c} y}{{ }^{c} z^{2}} & -\frac{{ }^{c} x}{{ }^{c} z}
\end{array}\right)
$$

である. 画像中の特徴点速度 ${ }^{I} \dot{p}$ とカメラの移動速度 $\boldsymbol{u}$ を関係づける行列 $\boldsymbol{J}$ は, イメージャコビアンと呼ばれる.

ここで, ステレオ視のモデル (1)〜 (4) 式より次式が 得られる.

$$
\begin{aligned}
& { }^{c} x=\frac{b}{2} \frac{{ }^{l} x+{ }^{r} x}{{ }^{l} x-{ }^{r} x} \\
& { }^{c} y={ }^{l} y \frac{b}{{ }^{l} x-{ }^{r} x}={ }^{r} y \frac{b}{{ }^{l} x-{ }^{r} x} \\
& { }^{c} z=f \frac{b}{{ }^{l} x-{ }^{r} x}
\end{aligned}
$$

したがって，（14）（16）式を（13）式に代入すれば，ス テレオ視におけるイメージャコビアンは次式のようになる.

$$
\boldsymbol{J}=\left(\begin{array}{cccc}
-\frac{s}{b} & 0 & { }^{l} x \frac{s}{b f} & \frac{{ }^{l} x^{l} y}{f} \\
-\frac{s}{b} & 0 & { }^{r} x \frac{s}{b f} & \frac{{ }^{r} x^{l} y}{f} \\
0 & -\frac{s}{b} & { }^{l} y \frac{s}{b f} & \frac{{ }^{l} y^{2}}{f}+f \\
0 & -\frac{s}{b}{ }^{l} y \frac{s}{b f} & \frac{{ }^{l} y^{2}}{f}+f \\
& \frac{-{ }^{l} x\left({ }^{l} x+{ }^{r} x\right)}{2 f}-f & { }^{l} y \\
& \frac{-{ }^{r} x\left({ }^{r} x+{ }^{l} x\right)}{2 f}-f & { }^{l} y \\
& -{ }^{l} y \frac{{ }^{l} x+{ }^{r} x}{2 f} & -\frac{{ }^{l} x+{ }^{r} x}{2} \\
& -{ }^{l} y \frac{{ }^{l} x+{ }^{r} x}{2 f} & -\frac{{ }^{l} x+{ }^{r} x}{2}
\end{array}\right)
$$

こてに, $s={ }^{l} x-{ }^{r} x$ で特徴点の視差を表わしている.

以上は, 特徴点が 1 点の場合での議論であるが, 実際 の制御を行う際は，以下のように複数の特徴点を用いて 制御を実現する.

画像中に $n$ 個の特徴点が得られている時, 各特徵 点の画像中の座標より (17) 式のイメージャコビアン $J_{1}, \cdots, J_{n}$ が得られるので, 乙れらをまとめて,

$$
J_{\text {image }}=\left(\begin{array}{c}
J_{1} \\
\vdots \\
J_{n}
\end{array}\right)
$$

と記述する. 乙れにより, 複数の特徴点の場合です特徴 点速度とカメラの移動速度は次式の関係で表わすことが できる.

$$
{ }^{I} \dot{\boldsymbol{p}}=\boldsymbol{J}_{\text {image }} \boldsymbol{u}
$$

ただし，特徴点のステレオ対応および時間的な対応はと れているあのとする. また, $\boldsymbol{J}_{\text {image }}$ はフルランクと仮 定する（実際には，乙の仮定が満たされるように，特徴 点の選択, その個数の決定を行うあのとする).

\section{3 フィードバック入力の生成}

ビジュアル・サーボでは, 画像中の特徴点の現在位置 が目標位置に達するようにマニピュレータを制御する. このときのフィードバック入力は次のようにして生成す $ろ^{3)}$.

${ }^{I} \boldsymbol{p}$ と画像中の特徵点の目標位置 ${ }^{I} \boldsymbol{p}_{d}$ との誤差関数を 次式のように定義する.

$$
\boldsymbol{e}=\boldsymbol{C}\left({ }^{I} \boldsymbol{p}^{-I} \boldsymbol{p}_{d}\right)
$$

ここに，C は系を安定化する適当な行列である．乙の とき, フィードバック入力を, $\lambda$ をゲインとして次のよ うに与える.

$$
\boldsymbol{u}=-\lambda \boldsymbol{e}
$$

ビジュアル・サーボを実現するためには, 誤差システム

$$
\begin{aligned}
\dot{\boldsymbol{e}} & =\frac{\partial \boldsymbol{e}}{\partial t} \\
& =\boldsymbol{C} \frac{\partial^{I} \boldsymbol{p}}{\partial t} \\
& =\boldsymbol{C}^{I} \dot{\boldsymbol{p}} \\
& =\boldsymbol{C} \boldsymbol{J}_{\mathrm{image}} \boldsymbol{u} \\
& =-\lambda \boldsymbol{C} \boldsymbol{J}_{\mathrm{image}} \boldsymbol{e}
\end{aligned}
$$

が収束するような $\boldsymbol{C}$ を選べば良い. こてではローカル な収束性を保証するための $\boldsymbol{C}$ の値として, $\boldsymbol{C} \boldsymbol{J}_{\text {image }}>0$ であり，かつ入力が過大とならないようなイメージャコ ビアン $\boldsymbol{J}_{\text {image }}$ の疑似逆行列

$$
\boldsymbol{J}_{\text {image }}^{+}=\left(\boldsymbol{J}_{\text {image }}^{\mathrm{T}} \boldsymbol{J}_{\text {image }}\right)^{-1} \boldsymbol{J}_{\text {image }}^{\mathrm{T}}
$$


を用いた，すなわち，フィードバック入力は，

$$
\boldsymbol{u}=-\lambda \boldsymbol{J}_{\text {image }}^{+}\left({ }^{I} \boldsymbol{p}^{-I} \boldsymbol{p}_{d}\right)
$$

となる. 疑似逆行列 $\boldsymbol{J}_{\text {image }}^{+}$は，その各要素がパラメー 夕誤差を含んでいても $\boldsymbol{C J}_{\text {image }}>0$ を満たすてとから, ロバスト安定なシステムを実現することができる.

ての入力により, Fig. 3 に示すような閉ループシス テムが構筑される.なお, ロボットシステムは, カメラ 速度 $\boldsymbol{u}$ の入力より関節目標速度 $\dot{\boldsymbol{q}}_{\boldsymbol{d}}$ を生成し, コントロー ラ内で理想的な速度サーボ系が構成されているとする.

また， $\boldsymbol{J}_{\text {i mage }}$ は $4 n \times 6$ 行列になるので，その疑似逆行 列 $\boldsymbol{J}_{\text {image }}^{+}$は $6 \times 4 n$ 行列となり， 6 自由度に対応する フィードバック入力 (24) 式が得ら机る.

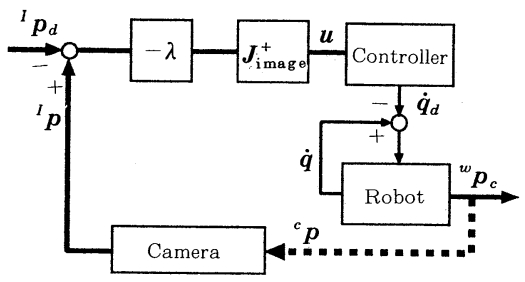

Fig. 3 Block diagram of feedback system

\section{3. 単眼視との比較}

単眼視に抢けるJ は次のようになる2).

$$
\boldsymbol{J}=f\left(\begin{array}{rrrr}
-\frac{1}{{ }^{c} z} & 0 & \frac{{ }^{c} x}{{ }^{c} z^{2}} & \frac{{ }^{c} x^{c} y}{{ }^{c} z} \\
0 & -\frac{1}{{ }^{c} z} & \frac{{ }^{c} y}{{ }^{c} z^{2}} & 1+\frac{{ }^{c} y^{2}}{{ }^{c} z^{2}} \\
& -\left(1+\frac{{ }^{c} x^{2}}{{ }^{c} x^{2}}\right) & \frac{{ }^{c} y}{{ }^{c} z} \\
& -\frac{{ }^{c} x^{c} y}{{ }^{c} z^{2}} & -\frac{{ }^{c} x}{{ }^{c} z}
\end{array}\right)
$$

いま，単眼視での画像座標系を $m$ 之定義する．乙の とき, カメラ座標系で ${ }^{c} \boldsymbol{p}=\left({ }^{c} x^{c} y^{c} z\right)^{\mathrm{T}}$ と表わされる環 境中の点 $p$ の単眼画像中に写る像を ${ }^{m} \boldsymbol{p}=\left({ }^{m} x,{ }^{m} y\right)$ と すると次式が成立する.

$$
\begin{aligned}
& { }^{m} x=f \frac{{ }^{c} x}{{ }^{c} z} \\
& { }^{m} y=f \frac{{ }^{c} y}{{ }^{c} z}
\end{aligned}
$$

（26），(27）式を（25）式に代入すると，

$$
\boldsymbol{J}=\left(\begin{array}{rrrrr}
-\frac{f}{{ }^{c} z} & 0 & \frac{{ }^{m} x}{{ }^{c} z} & \frac{{ }^{m} x^{m} y}{f} & \\
0 & -\frac{f}{{ }^{c} z} & \frac{{ }^{m} y}{{ }^{c} z} & \frac{{ }^{m} y^{2}+f^{2}}{f^{2}} & \\
& -\frac{{ }^{m} x^{2}+f^{2}}{f^{2}} & { }^{m} y \\
& -\frac{{ }^{m} x^{m} y}{f} & -{ }^{m} x
\end{array}\right)
$$

となる。

（17）式と（28）式を比較すると，ステレオ視では $\boldsymbol{J} に$ 特徴点の奥行きに対応した視差 $s$ が入っているのに対し て, 単眼視の場合にはてれが $z$ というカメラ座標系で 表わされた項となっている.

したがって，焦点距離 $f$ 基線長 $b$ を与えれば，ステ レオ視では $J$ のすべての項を画像上の座標で記述でき るので, 全く画像情報のみでフィードバック入力を生成 することができる，一方，単眼視の場合は，画像中の座 標とカメラ座標に执ける奥行き ${ }^{c} z$ の両方が入り混じっ ているため, 画像中の情報のみを用いてビジュアル ・ フィードバックを行うことはできず, 対象物体のモデル をあらかじ持って扔く之か，カメラ座標系から見た奥 行き方向の目標位置 ${ }^{c} z$ が与えられていなければならな い. このため, 単眼視ではイメージヤコビアンの疑似逆行 列 $\boldsymbol{J}_{\text {image }}^{+}$を求める際に, 目標点で近似した值しか取れ ないが，ステレオ視の場合は安定領域が広く，フィード バック入力生成時に毎回計算するととが可能なので, 安 定領域を考虑する必要むなくなる。

また，相対位置と相対姿勢を一意に定めるには，単眼 視では特徵点が最低 4 点必要なのに対して，ステレオ視 では 3 点で十分である.

さらに，位置決めをより正確に行うためや，画像に含 まれるノイズの影響を減じるために，多くの特徴点を用 いる場合, 単眼視では現在の画像上の特徴点之目標状態 での特徽点との位置誤差がばらつくため, 上述の制御は ますます厳しいものになるととが予想される.

\section{4. シミュレーションおよび実験}

\section{1 シミュレーション}

シミュレーションにより単眼視の場合とステレオ視の 場合との比較検討を行った. シミュレーションでは, 対 象物体の特徵点は一辺 $200(\mathrm{~mm})$ の正方形の頂点を構 成する 4 点とした. 同条件での比較のため, ステレオ視 の場合にも特徵点を 4 点用いた. 各パラメータは, 焦点 距離 $f=8(\mathrm{~mm})$, 基線長 $b=120(\mathrm{~mm})$, サンプリ ングタイム $80(\mathrm{msec})$, ゲイン $\lambda=1$ である. 目標位置 ${ }^{c} \boldsymbol{p}_{\boldsymbol{d}}$ を(100 $\left.500 \quad 600\right)^{\mathrm{T}}(\mathrm{mm})$, 目標姿勢を $z^{-} \boldsymbol{y}-\boldsymbol{z}$ オ 
イラー角で $(\phi, \theta, \phi)=(0,0,0)$ (degree) とした. 初 期誤差は並進䛊差を $(-100-100-100)^{\mathrm{T}}(\mathrm{mm})$, 回転 誤差を $(\phi, \theta, \phi)=(10,10,10)$ (degree) とした. 画像 上の特徴点の現在位置と目標位置との間の誤差変化を, 単眼視の場合とステレオ視の場合それぞれについて Fig. 4 に示す.さらに, 画像上での特徽点の軌跡を, 単眼視とステレオ視のそれぞれの場合について Fig. 5 , Fig. 6 に示す. これらより, 単眼視の場合は収束が遅 く, オーバーシュートも大きいが, ステレオ視の場合は 収束が速く，オーバーシュートも小さいてとがわかる.

つぎに, 特徴点の取り方を変えて初期誤差を大きくとっ た場合の結果を示す. $150 \times 200(\mathrm{~mm})$ の長方形の頂点 を構成するような四つの特徴点に対して, 並進䛊差を
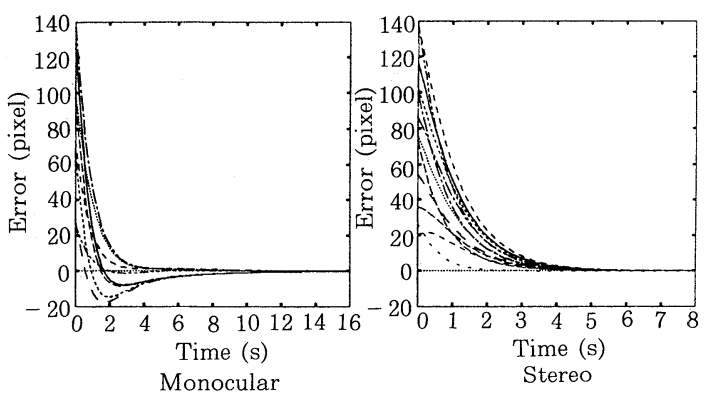

Fig. 4 Positional error in $x$ and $y$ axes (Simulation)

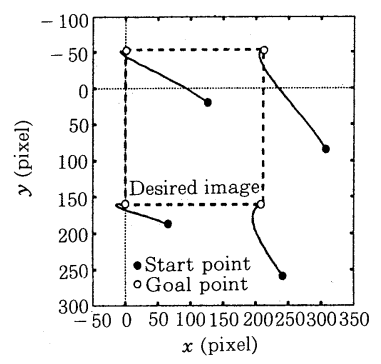

Fig. 5 Trajectories of feature points on the image (Simulation, Monocular)
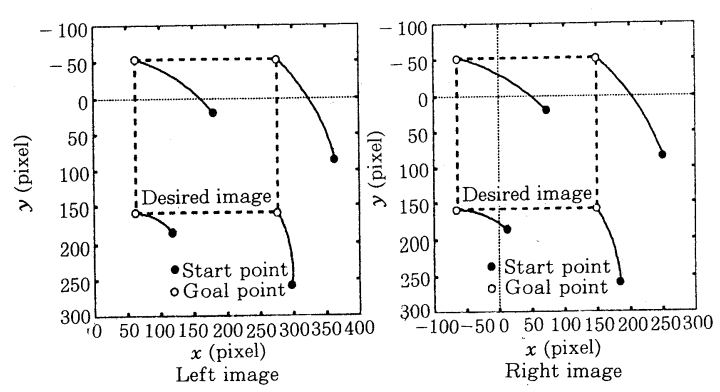

Fig. 6 Trajectories of feature points on the image (Simulation, Stereo)
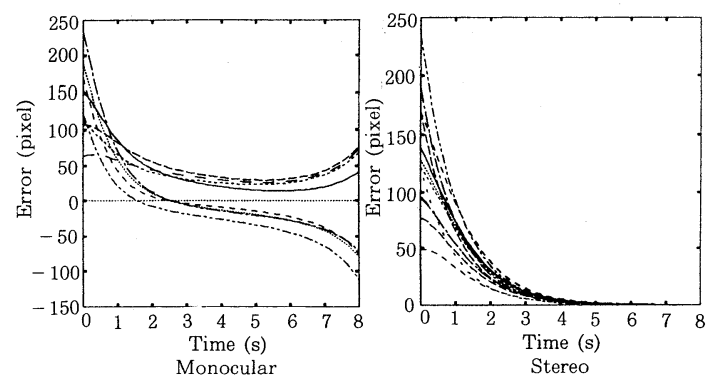

Fig. 7 Positional error in $x$ and $y$ axes (Simulation)

$(-200-200-200)^{\mathbf{T}}(\mathrm{mm})$ とし, その他の条件は同一 のままにした時の結果を Fig. 7 に示す. Fig. 7 より, 単眼視では発散してしまうが，てのような場合にもステ レオ視を用いれば, 収束するととがわかる. 乙れは, 単 眼視ではイメージャコビアンを目標位置での值に固定し ているため, 初期䛊差が大きいと正しいフィードバック 入力を生成できなくなるが，ステレオ視の場合では，イ メージャコビアンをマニピュレータの手先が移動するで とに更新できるため, 安定性を保証するフィードバック 入力を生成することが可能なためである.

\section{2 実 験}

実験は, 6 自由度ロボット（川崎重工 PH260）の手 先にステレオカメラ (カメラ本体 : 竹中システム機器 $\mathrm{TM}-745 \mathrm{H}$, レンズ : 同 CLS813 各 2 台）を取り付け た装置を用い（Fig.8参照)，一辺 $87(\mathrm{~mm})$ の正三角 形を構成する頂点上に, 半径 $20(\mathrm{~mm})$ の円板 3 枚を対 象物体に配置することにより特徴点とした. なお, 手先 に取り付けられたステレオカメラは, 㛜密なキャリブレー ションを行っていないが, その影響は出ていない. ステ レオ画像は 2 枚の画像入力装置（コンカレント TRPIMG）によりリアルタイムに二值化されパラレルに 取り込まれ, 2 台のトランスピュータ（コンカレント TRPM-402）で各特徴点の重心座標がパラレルに計算 される. このとき, 特徵点のステレオ対応および時間的 な対応は, 初回のサンプリング時には与えているが, 2 回目のサンプリング以降は, 左右の画像でそれぞれ独 立に, 前回のサンプリング時に特徵点があった場所の近 傍で探索を行うことにより, 特徵点の時間的な対応とス テレオ対応を取っている. 特徵点の座標值は制御用のト ランスピュータに送られ, 手先速度が計算される. その 結果は RS-232C を通じてロボットのコントローラに 送られ，コントローラ内の速度サーボ系によりロボット が制御される (Fig. 8 参照). 制御ループは 1 ループ 約 $80(\mathrm{msec})$ であり, 内訳は, 画像の取り込みに約 $33(\mathrm{msec})$, 画像中の特徴点座標の計算に約 2 (msec), 


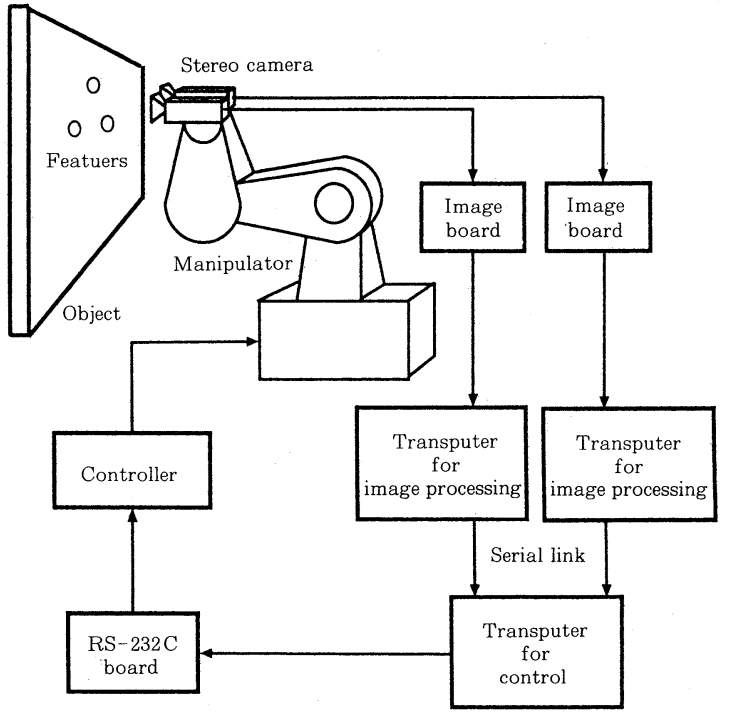

Fig. 8 Experimental system

制御入力の計算に約 $5(\mathrm{~ms})$, ロボットのコントローラ との通信に約 $40(\mathrm{~ms})$ である. RS-232C を使用せず に直接コントローラに速度信号を入力できれば，さらに 高速なサーボが実現できる。

また, 目標位置を ${ }^{c} \boldsymbol{p}_{\boldsymbol{d}}=\left(\begin{array}{lll}0 & 0 & 600\end{array}\right)^{\mathrm{T}}(\mathrm{mm})$, 目標姿 勢は $z-y-z$ オイラー角で $(\phi, \theta, \phi)=(0,0,0)$ (degree) とし, 初期誤差を並進誤差 $(505050)^{\mathrm{T}}(\mathrm{mm})$ とした.

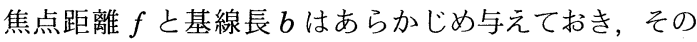
他のパラメータはシミュレーションの場合と同じとした。 画像上の特徴点の目標位置と現在位置との誤差変化の様 子を Fig. 9 亿，画像上の特徴点の移動軌跡を Fig. 10 に示す。

これらの図より，厳密なキャリブレーションを行って いなくても目標位置へ収束するてとがわかる。なお，グ ラフが振動しているのは，ロボットのコントローラのハー ド上の理由のためである.
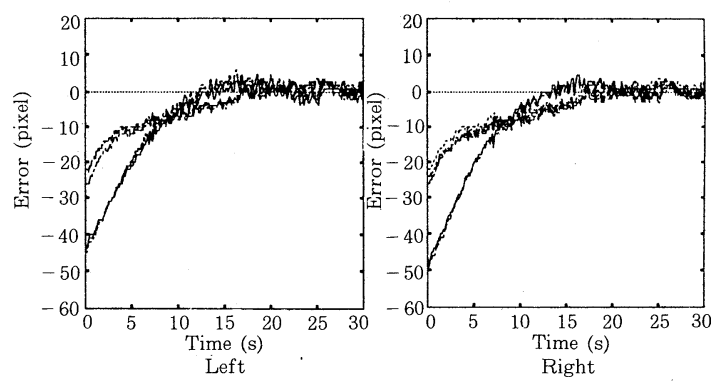

Fig. 9 Positional error in $x$ and $y$ axes (Experiment, Stereo)
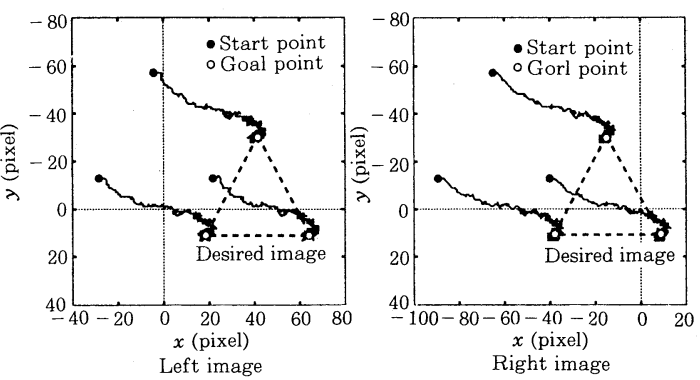

Fig. 10 Trajectories of feature points on the images (Experiment, Stereo)

\section{5.おわりに}

本論文では，マニピュレータの手先にカメラを取り付 けたハンドアイシステムに拈けるビジュアルフィードバッ ク制御に関して，従来用いられていた単眼視に抢ける問 題点を指摘し，その原因がイメージャコビアンに起因す るととを述べた，それらの問題点の解決方法としてステ レオ視を用いるととを提案し，ステレオ視におけるイメー ジャコビアンを検討した，それにより，イメージャコビ アンをカメラ位置ごとに正しく計算できるととを見い出 し，対象物体のモデルや目標相対距離を与える必要がな いとと, 初期誤差によらず収束するという利点を述べた. また，シミュレーションおよび実験により本手法の有効 性を確かめた.

ビジュアル・サーボでは，画像でのノイズや量子化誤 差，特徵点の選び方などの問題が多々存在する. 今後は, これらの問題についてあステレオ視を利用するてとによ り，解決をはかりたい。

\section{参 考 文 献}

1) L. E. Weiss, A. C. Sanderson and C. P. Neuman : Dynamic Sensor-Based Control of Robots with Visual Feedback ; IEEE Journal of Robotics and Automation, Vol. RA-3, No. 5, pp. 404 417 (1987)

2) K. Hashimoto, T. Kimoto, T. Ebine and H. Kimura Manipulator Control with Image-Based Visual Servo; Proc. of the IEEE Int. Conf. on Robotics and Automation, pp. 2267 2272 (1991)

3) F. Chaumette, P. Rives and B. Espiau : Positioning of a Robot with Respect to an Object, Tracking It and Estimating Its Velocity by Visual Servoing ; Proc. of the IEEE Int. Conf. on Robotics and Automation, pp. 2248 2253 (1991)

4) K. Hashimoto, T. Ebine and H. Kimura : Dynamic Visual Feedback Control for a Hand-Eye Manipulator ; Proc. of the IEEE/RSJ Int. Conf. on Intelligent Robots and Systems, pp. 1863 1868 (1992)

5) B. Espiau, F. Chaumette and P. Rives: A New Approach to Visual Servoing in Robotics ; IEEE Transactions on Robotics and Automation, Vol. 8, No. 3, pp. 313 326 (1992) 
